\title{
Financial Outlook of the United States Steel Industry and Its Role in the Economy Moving Forward
}

\author{
Samuel F. Nassar \\ Brandeis International Business School, Brandeis University, Waltham, MA, USA \\ Email: samnassar00@gmail.com
}

How to cite this paper: Nassar, S.F. (2019) Financial Outlook of the United States Steel Industry and Its Role in the Economy Moving Forward. iBusiness, 11, 51-56. https://doi.org/10.4236/ib.2019.113005

Received: August 28, 2019

Accepted: September 16, 2019

Published: September 19, 2019

Copyright $\odot 2019$ by author(s) and Scientific Research Publishing Inc. This work is licensed under the Creative Commons Attribution International License (CC BY 4.0).

http://creativecommons.org/licenses/by/4.0/

\section{(c) (i) Open Access}

\begin{abstract}
The US economy is an ever-evolving entity: with continuous spurs of technological innovation, massive corporations with prodigious influence, a government with the ability to sway the fate of entire industries, and a stock market that tracks these rapid transformations down to the minute. Despite this constant evolution, steel has remained a central fixture of the economic structure for the majority of US history. However, the recent development of advanced manufacturing and adoption of material counterparts has made the future status of steel uncertain. In my writing, I will determine the current state of steel, how its influence in the US economy will continue to evolve, and the financial ramifications of these changes. I examine the impacts of the current global trade war and the tariffs implemented by the US on the success of the domestic steel market. Furthermore, I discuss the rationale for investing in steel, and analyze individual companies within the steel industry's extensive supply chain.
\end{abstract}

\section{Keywords}

Steel Industry, US Economy, Technological Innovation

\section{Introduction}

Steel is a foundational piece of any nation's economy and is customarily a catalyst for the early stages of economic development. An appreciable steel industry allows a country to progress through the industrial phase of development which is crucial for modernization. In the US, for example, the presence of steel is evident in nearly all aspects of daily life. It is the only material that is present in the homes we live in, the vehicles we drive, and nearly all the goods and services we 
encounter on a daily basis. For infrastructure and automobile production, steel amounts to greater than $50 \%$ of the weight used for production, and around $75 \%$ of household appliances consist of steel [1]. Lately, the metal has grown into a vital component for manufacturing and technological development in the revitalized healthcare and energy sectors.

Though steel remains a backbone of the US economy it is no longer as central to economic growth as it once was. According to research by the American Economic Review, around 75\% of the industry's workforce was shed between 1962 and 2005 [2]. Nonetheless, with the advent of modern technology, overall productivity has grown by $38 \%$ with worker output increasing fivefold. This speaks to the shift away from the industrial-based economy and the onset of modern manufacturing for American companies. While the US has progressed to a more contemporary economy, China has emerged as the indisputable frontrunner in steel production and consumption worldwide.

\section{Recent Developments in the Steel Market}

Rapid developments in engineering and technology have allowed the US to initiate the generation of alternative materials without focusing on stability in the steel industry. Imbalances in both substitute and complementary goods of steel have led to seemingly arbitrary variations. Because of this unpredictability, the steel market has faced significant disparity in price, relative to conventional market fluctuations in modern times.

Even when juxtaposed with similar commodities and other basic metals, steel has appeared notably volatile, particularly in recent years. Since the turn of the century, and especially amidst the Great Recession of 2008, the steel market has been subject to unsettling swings. A lack of liquidity, government interventions, leverage in futures markets, and nature itself, are a number of the many factors why volatility in the industry has come to be expected.

Most recently, a global trade war has induced politically influenced maneuvers that have deterred advancement in the steel industry. In early March of 2018, the US imposed 25 percent tariffs on imported steel under section 232 of the 1962 Trade Expansion Act. Though the inauspicious effects of the tariffs can now be observed 18 months later, they did initially provide a boost in the US steel market and a surge in stock prices. With the ability to raise prices while still outcompeting foreign manufacturers, domestic plants were able to increase their revenues substantially in the ensuing months. For Nucor, the largest American steel manufacturer, the tariffs led to the most prosperous second-quarter in company history with a more than doubling of their profits within just a few months of the tariffs' enactment [3]. Likewise, the jump in steel prices and greater revenue allowed many firms to hire additional workers, and by June 2018 United States Steel, the second-largest producer of steel, had reopened their second blast furnace since the tariffs were implemented.

However, these results proved unsustainable, and just a year later the same 
company announced that it would be closing three blast furnaces. To account for falling prices and diminishing demand, a number of other companies have been cutting production at their mills as well.

The evidence of these shortcomings is made clear when evaluating the performance of leading stocks in the steel industry. Since the tariffs were put in place, the Vaneck Vectors Steel ETF (SLX), which serves as a representation of the overall steel industry, has significantly underperformed when compared with the market as a whole. The steel market initially outpaced the market as a whole in the aftermath of the announcement and implementation of the tariffs in March 2018, but that momentum has proved unsustainable. Since then, stock prices for steel have fallen over $30 \%$, to hit well below pre-tariff levels, while the economy has peaked at decade highs. In particular, many of the foremost players in the steel industry have faced significant repercussions. US Steel, for instance, has lost $70 \%$ of its market value, around $\$ 6$ billion [4], in that time, and they are hardly alone. Other companies have also struggled immensely. Even Nucor, whose CEO has continued to publicly praise the tariffs, has seen its stock fall over $20 \%$ in the last year.

These stock evaluations provide only a trivial glimpse into the current scope of the steel industry as a whole. In order to grasp the entirety of its current condition and be able to effectively look forward, a more basic analysis of the financial stability of individual companies within the steel supply chain is most practical.

\section{Financial State of Steel}

Among the current leaders of steel production in the US are Nucor, US Steel, Steel Dynamics, and AK Steel. Nucor and US Steel alone account for nearly half of all steel production in the US However, while US steel uses blast furnaces, which rely mainly on iron ore, to produce the majority of their steel, Nucor uses the more modern electric arc furnaces which utilize electricity and recycled metals to produce their steel. Though variance across the industry must be accounted for, in my analysis I have focused on US Steel because it most accurately mirrors the overall health of the steel industry.

Assessing the financial statements and operations of US Steel [4] for just the previous two years reveals a relatively bleak outlook. In the recent announcement of Quarter 2 performance, they reported that the company surpassed both earnings and revenue estimates for the quarter.

However, the quarterly earnings and revenue of $\$ 0.45$ per share and $\$ 3.55$ billion fell well short of the $\$ 1.46$ per share and $\$ 3.61$ billion posted a year ago. Additionally, the net earnings of $\$ 68$ million or $\$ 0.39$ per share for the quarter were down from $\$ 214$ million or $\$ 1.20$ in Quarter 2 of 2018, a 68\% reduction. These losses would generally spell trouble, yet US Steel has been able to simultaneously reduce their long term debt by around $\$ 300$ million with a current $\$ 651$ billion in cash and a 0.62 debt to equity ratio, which is manageable for a company of 
their stature.

These measures indicate that during periods of growth US Steel should be able to maintain moderate success, but in downturns in the steel industry, they will presumably suffer. Despite a relatively stable balance sheet and financial statements, they lack significant opportunity for future growth.

Though an examination of the financial status of the US Steel as outlined above provides a practical rendering of the present state of a major producer in the US steel market, each piece of the supply chain is vital to the overall health of the industry and complications in any of the steps.

\section{Supply Chain of the Industry}

Producing steel generally begins with the extraction of iron ore and other metals through mining, so examining Rio Tinto, the world's largest accumulator of iron ore, seems most reasonable.

Despite many steel manufacturers turning to recycled metals as a means of creating steel, iron ore remains the foremost substance in steel production, and Rio Tinto is the clear leader in its mining.

Closing out the first half of 2019 Rio Tinto reported [5] underlying earnings of $\$ 4.93$ billion; their largest profit in five years, and a substantial increase from the $\$ 4.42$ billion in the same time span a year ago. The growth was predominantly a result of rising prices for iron ore, which is the predominant element in steel production. Comparing the same periods, net earnings in iron ore alone have risen from $\$ 3.2$ billion to $\$ 4.5$ billion. Although the rise in iron ore prices proves profitable for mining companies like Rio Tinto, the increased cost must either be absorbed by steel manufacturers or passed on in the supply chain.

Furthermore, by analyzing service centers and similar intermediaries in the supply chain of steel, anticipating the upcoming actions of both the steel producers that supply them and their wide customer base becomes attainable. Olympic Steel, one of the largest metals service centers in the country, serves as an appropriate example for doing this. A loss in earnings per share of nearly $90 \%$, from $\$ 1.49$ in quarter 2 of 2018 to just $\$ 0.16$ this year, and a \$23 million drop in revenues.

[6] supports the presumption that steel producers would pass the consequences of higher input prices onto their customers. This could potentially be shown in the final price of a myriad of products that rely on steel as an input. While the direct impacts of steel account for an already massive steel industry, the effects of its supply chain are far-reaching both nationally and globally.

In a study done by Oxford Economics [7], they found that on a global scale the steel industry and the supply chain that it contributes to is accountable for \$2.9 trillion, which is around 4\% of global GDP, and employs 96 million people globally. In the US alone, around 2 million jobs and $\$ 520$ billion are supported by the steel industry.

Steel is an indispensable part of dozens of industries and countless others rely 
on it in order to function optimally in various regards. As previously entailed, a problem at any step of the supply chain has pronounced effects that could carry over to consumers. For example, the world's largest manufacturer of construction equipment, Caterpillar, was decimated by the tariffs. In 2018 their stock fell $19.4 \%$ and they faced losses of over $\$ 100$ million. Even Ford, which is known for being a true American organization, has faced ramifications since the tariffs were put in place. In September 2018 their CEO, Jim Hackett, told Bloomberg that the tariffs had already cost the company over $\$ 1$ billion in lost profits. Companies such as Caterpillar and Ford are vital to the foundation of our economy, and their struggles could cause problems in economic growth and development. Although the link between steel and economic prosperity in well-developed economies such as the US is no longer so profound, the repercussions from the tariffs indicate that steel still has at least some economic influence.

\section{Conclusions}

Recent circumstances have resulted in an overwhelmingly negative impact on steel and correlated industries in its supply chain. Some may argue that because of this lackluster performance, now would be a good time to invest in steel, with the potential for profit in a recovery. However, with an ongoing trade war and looming disputes with China and other foreign powers, the immediate future in the steel market is not as promising as they may envision. With the onset of further development of competing materials, I remain wary of the future prospects for the steel industry.

Moving forward, further automation in steel manufacturing will continue to reduce the need for employment in the industry, which will potentially conserve a considerable profit but leaves little hope for substantial growth. Unless stocks plummet below reasonable levels, placing your hopes in the recovery would not be advisable. As time progresses, steel will continue to be a relevant component of the American economy, but as society continues to modernize, its importance will most likely continue to diminish.

\section{Conflicts of Interest}

The authors declare no conflicts of interest regarding the publication of this paper.

\section{References}

[1] American iron and Steel Institute (2019). https://www.steel.org/steel-markets/appliances

[2] Collard-Wexler, A. and De Loecker, J. (2015) Reallocation and Technology: Evidence from the US Steel Industry. American Economic Review, 105, 131-171. https://pubs.aeaweb.org/doi/pdfplus/10.1257/aer.20130090 https://doi.org/10.1257/aer.20130090

[3] Nucor (2019). https://nucor.com/investors/

[4] United States Steel Corporation (2019). https://www.ussteel.com/investors/reports-filings 
[5] Rio Tinto Limited (2019). https://www.riotinto.com/investors-87.aspx

[6] Olympic Steel (2019). https://olysteel.com/

[7] World Steel Association (2019) The Role of Steel Manufacturing in the Global Economy. https://www.worldsteel.org/en/dam/jcr:fdf44918-de3b-455b-9083-f770afa4a214/OE \%2520Executive\%2520Summary.pdf 